\title{
Dişavurumcu Sanat Terapisinin Psikolojik Belirtiler İle Bilişsel İşlevlere Etkisi
}

\author{
DOI: $10.26466 /$ opus.337250
}

\section{Volkan Demir}

* Üsküdar Üniversitesi, Sosyal Bilimler Enstitüsü, Psikoloji Bölümü, Doktora Öğrencisi,İstanbul. E-Posta: demir.volkan@outlook.comＯRCID: 0000-0002-8148-8647

\section{Öz}

Bu araştırma, dışavurumcu sanat terapisi programının bireylerin psikolojik belirtileri, umutsuzluk, otomatik düşünceler ve fonksiyonel olmayan tutumlar üzerindeki etkisini araştırmak amactyla yapılmıştır. Araştırmanın çalışma grubunu, yaşları 24-62 arasında değişen 9 kadın 2 erkek toplam 11 katılımo oluşturmaktadır. Çalışmada katılımcılara başlangıçta ve dokuz haftanın sonunda Kısa Semptom Envanteri (KSE), Beck Umutsuzluk Ölçeği (BUÖ), Otomatik Düşünceler Ölçeği (ODÖ) ve Fonksiyonel Olmayan Tutumlar Ölçeği (FOTÖ) verilmiştir. Araştırmada çalışma grubuna 9 oturumdan oluşan 180 dakika süren dışavurumcu sanat terapisi programı uygulanmıştır. Tek grup öntest - sontest kontrol grupsuz desenin kullanıldığı çalışmada veriler, Wilcoxon İşaretli Stra Testi ile çözümlenmiştir. Yapılan analizler dışavurumcu sanat terapisi programının, bireylerin umutsuzluk, otomatik düşünceler, fonksiyonel olmayan tutumlar ve Kısa Semptom Envanteri (KSE) alt ölçeklerinden somatizasyon, obsesif kompulsif bozukluk, kişiler arası duyarlllık, depresyon, anksiyete, fobik anksiyete, paranoid düşünce ve psikotizm belirti düzeylerini azaltmada olumlu bir etkiye sahip olduğunu ancak öfke düzeylerini azaltmada etkili olmadı̆̆ını göstermektedir.

Anahtar Kelimeler: Dışavurumcu sanat terapisi, psikolojik belirti, umutsuzluk, otomatik düşünceler, fonksiyonel olmayan tutumlar 


\title{
The Effects Of An Expressive Art Therapy Program On Psychological Symptoms And Cognitive Functi- ons
}

\author{
DOI: $10.26466 /$ opus. 337250
}

\begin{abstract}
This study was conducted to investigate the impact of expressive arts therapy program on psychological symptoms, hopelessness, automatic thoughts and dysfunctional attitudes of individuals. The study group consisted of 11 participants (2 men, 9 women), ages ranging from 24 to 62. Brief Symptom Inventory (BSI), Beck Hopelessness Scale (BHS), Automatic Thoughts Scale (SAS) and Dysfunctional Attitude Scale (DAS) have been applied to all participants initially and after nine weeks of therapy. An expressive arts therapy program lasting a total of 180 minutes in 9 sessions was implemented. One group pretest - posttest control study design was used and data were analyzed using the Wilcoxon Signed Rank test. The results suggested that expressive art therapy program had positive effects on individuals' despair, automatic thoughts, dysfunctional attitudes and Brief Symptom Inventory (BSI) somatization subscale, obsessive-compulsive disorder, interpersonal sensitivity, depression, anxiety, phobic anxiety, paranoid thinking and psychotism; but it was not effective at reducing anger levels.
\end{abstract}

Key Words : Expressive arts therapy, psychological symptoms, hopelessness, automatic thoughts, dysfunctional attitude 


\section{Giriş}

Sanat terapisi; bireylerde olumlu bir gelişmeye neden olmak, çatışmaları çözümlemek, bedensel ve ruhsal problemleri azaltmak, sorun çözmek, stresle başa çıkmada yardımcı olmak üzere tanı ve tedaviyi sağlamada çeşitli sanat materyallerinin kullanımı olarak tanımlanmaktadır (Coşkun, Yıldız ve Yazıc1 2010; Case ve Dalley, 2006; Geue ve ark., 2010; Malchiodi, 2005). Sanat terapisi, farklı sanat materyallerinin duygusal özelliklerini ve klasik psikoterapi yaklaşımlarını birleştirir (Edwards, 2004). Bu yaklaşım, sanat uygulamaları olan resim, müzik, tiyatro, sinema, hareket ve dans gibi alanındaki bütün faaliyetleri içerir (Malchiodi, 2003).

Sanat terapisiyle uğraşan terapistler çeşitli kuramsal bakış açısına sahip olabiliriler. Örneğin psikodinamik, bilişsel-davranışçı ya da varoluşçu kuramın bakış açısıyla çalışabilmektedirler. Psikoterapötik yönelim sanatla terapi sürecinin çerçevesini belirler ve dışavurulanın anlamlandırılmasına yardımcı olur. Birçok kuramın temelindeki yaygın inanış bilinçd1şının dışavurulmasıdır (Malchiodi, 2003). Sanat terapisi, bilinçdışını bilince getirmede ve terapötik ilişkiyi kolaylaştırıcı bir etkiye sahiptir (Wilson, 1995).

Sanat terapisinin keşfedilmesi 1940 yıllara dayanır ve profesyonelleşmesi 1960'larda başlamıştır. Sanat terapisi terimi sanatçı Adrian Hill tarafından 1942 yılında tüberküloz hastalarıyla birlikte yaptığı çalışmayı tanımlamak amacıyla kullanılmıştır. Hill, bu çalışmasında resim yapmanın sadece hastaların vakit geçirmelerini sağlamakla kalmayıp, aynı zamanda anksiyete ve travmalarını ifade etmek için bir araç olduğunu keşfetmiştir (Akhan, 2012; Case ve Dalley, 2006; Malchiodi, 2005).

Sanatla terapi süreci, kendini ortaya koyma ve kendini fark etmeyi sağlamaktadır. Düşünce, duygu ve davranış biçimleriyle, içinde bulundukları çevrenin ortak diline yabancılaşan, kendi iç dünyasına çekilen bireyler grup süreci ilerledikçe diğer grup üyelerinin düşünce ve duygularını tanıma, kendi duygularını fark edip dile getirme ve uygun tepkiler gösterme konusunda olumlu gelişmeler göstermişlerdir.

Bireylerin davranışlarının başlamasında düşünceler önemli bir yere sahiptir (Eisen ve Kearney, 1995). Bireyin duygularını ve bununla ilişkili davranışlarına yön veren şeyin, herhangi bir durumun kendisi değil, ge- 
nellikle otomatik düşüncelerle kendisini belli eden, o duruma ilişkin yaptığı yorumlar olduğu vurgulanmaktadır (Beck, 2001). Beck (1976), bilinçliliğin akışında istemeden ortaya çıan düşünceler ve imgelere "otomatik düşünceler" ismini vermiştir. Otomatik düşünceler çoğunlukla olumsuzdur.

Fonksiyonel olmayan inançlar, çocukluk döneminde başlayan, yaşam boyu gelişen, genellikle değişmez ve kalıcı özellikte olan uygulamaları kapsar (Duy, 2003). Gerçekçi değildir; katıdır ve genellenmiştir, olumsuz duygulara neden olur ve yaşanan günlük deneyimlerle değişmezler. Bireyin ne yaparsa yapsın kendini iyi hissedebilmesi için başkaları tarafından onaylanması gerektiğine inanması, kendisini başarılı sayabilmek için her alanda başarılı olma zorunluluğunu hissetmesi ya da yaşamda her şeyin kontrol edilebileceğine inanması fonksiyonel olmayan tutumlara örnek olarak verilebilir (Beck ve ark., 1979). Bu çeşit fikir ve inançlar sürekli olarak otomatik düşünlerle desteklenmektedir. Yapılan araştırmalar, yüksek düzeyde fonksiyonel olmayan tutumlara sahip bireylerin çok sayıda olumsuz düşünceye sahip olduklarını, daha fazla umutsuzluktan söz ettiklerini ve daha yüksek düzeyde olumsuz yaşam olaylarına maruz kaldıklarını ortaya koymuştur (Norman, Miller ve Dow, 1988).

Umutsuzluk, bireyin geleceğe yönelik hedeflerine ulaşamaması, başarılı olmaya yönelik olumsuz inançlara sahip olması ve geleceğe dair motivasyonunu kaybetmesidir (Gençöz, Vatan ve Lester, 2006). Umutsuzluk bireyin sağlığı ve iyilik hali üzerindeki önemli etkileri sebebiyle birçok araştırmaya konu olmuştur. Yapılan bazı çalışmalar umutsuzluk ile otomatik düşünceler arasında bir ilişkinin olduğunu belirtmektedir (Beck ve ark., 2004; Corey, 2008; Çakar, 2014; Tümkaya, Çelik ve Aybek, 2011). Öte yandan otomatik düşüncelerin kayg1 (O'connor ve ark., 2002) ve depresif duygulanım (Dilbaz ve Seber, 1993; Cunningham, Gunn, Alladin ve Cawthorpe, 2008) gibi umutsuzluk ile doğrudan bağlantılı değişkenler ile de pozitif yönde bir ilişkisi olduğunu belirleyen araştırma sonuçlarıyla da benzerlik göstermektedir (Aydın, 1990). Sanat yoluyla bireyler yeni şeyler öğrenebilmektedirler. Öğrenme başarısı ise özgüveni arttırmaktadır. Bilgi birikimlerinin ve kişisel hikayelerin grup içerisindeki paylaşımı bireylerin geçmiş yaşantıları ile şimdiki durumlarının bütünleşmesine yardımcı olmakta, depresif belirtileri azaltmakta ve umut duygusunu ise arttırmaktadir (Kar ve Toros, 2015). 
Sanat terapisi yoluyla yaratıcı sürecin fiziksel ve ruhsal sağlıkta iyileşmeye neden olduğu ileri sürülmektedir. 55 kanser tanısı almış bireyler ile yapılan bir araştırmada sanat terapisi seansları sonrasında ağrıda, yorgunlukta ve kaygı düzeyinde anlamlı azalma olduğu tespit edilmiştir (Nainis ve ark., 2006). Şehirde yaşayan 300 birey ile yapılan diğer bir araştırmada sanat terapisi gruplarına katılan bireylerin daha az doktora gittikleri daha az ilaç kullandıkları ve sanat terapisi almayan gruba göre daha az depresif bulgu gösterdikleri ve kendilerini daha iyi hissettikleri saptanmiştır (aktaran Kar ve Toros, 2015).

$\mathrm{Bu}$ araştırmanın temel amacı "dışavurumcı sanat terapisi programı bireylerin psikolojik belirti, umutsuzluk, otomatik düşünceler ve fonksiyonel olmayan tutumlar düzeylerini etkilemekte midir? "sorusuna cevap aramaktır.

Belirlenen bu genel amaç doğrultusunda şu hipotezler test edilecektir:

1. Dışavurumcu sanat terapisi programına katılan çalışma grubundaki bireylerin kisa semptom envanteri son-test puan ortalamaları ön-test puan ortalamalarına oranla anlamlı düzeyde azalacaktır.

2. Dişavurumcu sanat terapisi programına katılan çalışma grubundaki bireylerin umutsuzluk son-test puan ortalamaları ön-test puan ortalamalarına oranla anlamlı düzeyde azalacaktır.

3. Dışavurumcu sanat terapisi programına katılan çalışma grubundaki bireylerin otomatik düşünceler son-test puan ortalamaları ön-test puan ortalamalarına oranla anlamlı düzeyde azalacaktır.

4. Dişavurumcu sanat terapisi programına katılan çalışma grubundaki bireylerin fonksiyonel olmayan tutumlar son-test puan ortalamaları ön-test puan ortalamalarına oranla anlamlı düzeyde azalacaktır.

\section{Yöntem}

Araştırmada, deneme modellerinden "Tek grup öntest - sontest kontrol grupsuz deney deseni" kullanılmıştır. Tek grup öntest - sontest modelinde gelişigüzel seçilmiş bir gruba bağımsız değişken uygulanır. Tek grup öntest - sontest modelinde hem deney öncesi (öntest) hem de deney sonrası (sontest) ölçmeler vardır (Karasar, 2014). 
Araştırmanın deseninin sembolik görünümü şu şekilde açıklanabilir.

$\mathrm{G}=$ işlem yapılan grup,

O1= katılımcılardan alınan ön ölçümü,

$\mathrm{X}=$ deneysel işlemi,

$\mathrm{O} 2=$ katılımcılardan alınan son ölçümü göstermektedir.

Tablo 1: Araştırmanın Deseninin Sembolik Görünümü

\begin{tabular}{llll}
\hline Grup & Öntest & İsslem & Sontest \\
\hline $\mathrm{G}$ & $\mathrm{O} 1$ & $\mathrm{X}$ & $\mathrm{O} 2$ \\
\hline
\end{tabular}

\section{Çalışma Grubu}

Katılımcılara araştırmanın amacı ve grup çalışmasının özellikleri konusunda bilgi verilerek katılımın gönüllülük ilkesine dayandığ 1 açıklanmış ve onam alınmıştır. Çalışmaya katılanların kişisel bilgilerinin başkalarına açıklanmayacağ

$\mathrm{Bu}$ araştırmada yer alan bireylerin seçimi için, sosyal medyada İstanbul ilinde ikamet eden, 20-65 yaş aralığında bireylere yönelik olarak 9 haftalık Dışavurumcu Sanat Terapisi duyurusu yapılmıştır. Duyuru sonucunda 43 birey başvuru yapmıştır. Bu kişilere Kişisel Bilgi Formu ve Kısa Semptom Envanteri (KSE), Beck Umutsuzluk Ölçeği (BUÖ), Otomatik Düşünceler Ölçeği (ODÖ) ve Fonksiyonel Olmayan Tutumlar Ölçeği (FOTÖ) uygulanmıştır. Araştırmaya kabul kriterleri olarak; uygulanan ölçeklerin puan sonuçlarına göre 'Orta' ve 'Yüksek' düzeyde puan ortalaması olan ve çalışmaya katılmayı kabul eden katılımcılar olarak belirlendi.

Araştırma Klinik ve Adli Psikoloji Derneğinde gerçekleştirilmiştir. Çalışma grubu 9 kadın 2 erkek olmak üzere 11 kişiden oluşmaktadır. Yaş sınırları minumum 24 maksimum 62 idi. Grubun eğitim durumuna bakıldığında 10 kişinin lisans, 1 kişinin ilkokul mezunu olduğu görülmektedir. Grubun medeni durumuna bakıldığında 5 kişinin bekar, 5 kişinin evli 1 kişinin de boşanmış olduğu görülmektedir.

16 yaşından küçük ve 65 yaşından büyük olanlar, çalışmada kullanılacak ölçekleri doldurabilecek düzeyde okuma-yazma bilmeyen bireyler, madde bağımlılığı olan bireyler ve kronik tıbbi bir hastalığı olan bireyler çalışmaya dahil edilmemiştir. 


\section{Veri Toplama Araçları}

Sosyodemografik Bilgi Formu: Katılımclara verilen bu form sosyodemografik özellikleri sorgulamak amacıyla araştırmacı tarafından hazırlanmıştır. Bu form ile yaş, cinsiyet, eğitim düzeyi, medeni durum, meslek, kullanılan ilaç tedavileri, alkol-madde kullanımı ve diğer fiziksel hastalıkları sorgulanmıştır.

Kısa Semptom Envanteri (KSE): Derogatis (1992) tarafından geliştirilmiş ve 0-4 arası puanlanan 53 maddelik kendini değerlendirme türü bir ölçektir. Ölçekten alınan toplam puanların yüksekliği, bireyin belirtilerinin sıklığını gösterir. KSE'nin Türkiye uyarlaması iki ayrı çalışma ile gerçekleştirilmiştir (Şahin ve Durak 1994, Şahin ve ark. 2002). Kısa Semptom Envanteri, SCL-90-R ile yapılan çalışmalar sonucunda ortaya çıkan SCL-90-R' nin kısa formudur. Kısa semptom envanteri çeşitli psikolojik belirtileri taramak amaciyla ergen ve yetişkinlere uygulanabilen bir kendini değerlendirme ölçeğidir. Dokuz alt ölçek ve üç global indeksten oluşur. Ölçeğin belirlenen 9 alt ölçeği sırasıyla, somatizasyon (2,7,23,29,30,33,37. maddeler), obsesif kompulsif semptom $(5,15,26,27,32,36$. maddeler), kişiler aras1 duyarlılik $(20,21,22,42$. maddeler), depresyon $(9,16,17,18,35,50$. maddeler), anksiyete $(1,12,19,38,45,49$. maddeler), hostilite $(6,13,40,41,46$. maddeler), fobik anksiyete $(8,28,31,43,47$. maddeler), paranoid düşünce $(4,10,24,48,51$. maddeler) ve psikotizm $(3,14,34,44,53$. maddeler) alt ölçekleri olarak oluşturulmuştur. Ek maddeler ise $(11,25,39,52$. maddeler) yeme içme bozuklukları, uyku bozuklukları, ölüm ve ölüm üzerine düşünceler ve suçluluk duyguları ile ilgili maddeler vardır.

Beck Umutsuzluk Ölçeği: Beck ve arkadaşları tarafından bireyin geleceğe yönelik karamsarlık düzeyini belirlemek amacıyla geliştirilmiştir (Beck, Lester ve Trexler, 1974). Beck Umutsuzluk Ölçeği, 20 maddelik kendini değerlendirme türü bir ölçek olup, puan ranjı 0-20 arasındadır. Gelecekle ilgili duygular, motivasyon kaybı ve gelecekle ilgili beklentiler olmak üzere üç alt boyuttan oluşmaktadır. Beck Umutsuzluk Ölçeği'nin uygulanmasında, katılımclardan kendisine uygun olan ifadeler için 'doğru', uygun olmayan ifadeler için 'yanlış' seçeneğini işaretlemeleri istenir. Ölçeğin puanlanması, her uyumlu yanıt için ' 1 ' puan, uyumsuz yanıt için ' 0 ' 
puan şeklindedir. Elde edilen aritmetik toplam 'umutsuzluk puanını oluşturur. Alınan puanların yüksekliği bireydeki umutsuzluğun yüksek olduğunu gösterir. Ölçeğin Türkçe'ye adaptasyon ve güvenirlik-geçerlik çalışmaları Seber (1991) ve Durak (1994) tarafından yapılmıştır.

Otomatik Düşünceler Ölçeği (ODÖ): Hollan ve Kendall'ın (1980) geliştirdiği "Otomatik Düşünceler Ölçeği (ODÖ)" kişinin kendine yönelik olumsuz değerlendirmelerin sıklığını ölçmeyi amaçlamaktadır. 1-5 arasında puanlanan ve 30 maddeden oluşan likert tipi bir ölçektir. Ölçeğin puan ranjı 30-150 arasındadır. Ölçekten alınan toplam puanların yüksekliği, bireyin otomatik olumsuz düşüncelerinin sıklıkla ortaya çıktığını gösterir (Savaşır ve Şahin, 1997). Ölçeğin Türkiye uyarlaması Aydın ve Aydın (1990) ile Şahin ve Şahin (1992) tarafından yapılmıştır. Ölçeğin yapılan faktör analizi sonucunda beş faktörden oluştuğu belirlenmiştir. Bu faktörler: kendine yönelik olumsuz düşünceler, şaşkınlık/ kaçma fantezileri, kişisel uyumsuzluk ve değişme istekleri, yalnızlık ve ümitsizliktir (Şahin ve Şahin, 1992). Türkçe ölçeğin Cronbach Alpha iç tutarlık katsayısı .93 olarak belirlenmiş; her bir ölçek maddesinin madde toplam korelasyonunun .37 ile .85 (Aydın ve Aydın, 1990) ve .35 ile .69 (Şahin ve Şahin 1992) arasinda değiştiği görülmüştür. Ölçeğin iki yarım test güvenirliğinin .91 (Şahin ve Şahin, 1992), test tekrar test güvenirlik katsayısının r=.77 (Aydın ve Aydın), ölçüt bağıntılı geçerliği için Beck Depresyon Envanteri ile korelasyonun .70 (Aydın ve Aydın) ve .75 (Şahin ve Şahin, 1992) olduğu belirlenmiştir.

Fonksiyonel Olmayan Tutumlar Ölçeği (FOTÖ): Fonksiyonel olmayan tutumları belirlemek amacı ile Weissman ve Beck (1978) tarafından geliştirilip Şahin ve Şahin (1992) tarafından Türkçe'ye uyarlanan ölçek 40 maddeden oluşmakta olup 7'li likert tipi bir ölçektir. 2, 6, 12, 17, 24, 29, 30, 35, 37 ve 40. maddelerin fonksiyonel olan tutumlara işaret ettiği varsayıldığından, bu maddeler ters olarak puanlanır. Puan aralığ $40-280$ 'dir. Weissman ve Beck'in yaptıkları güvenirlik çalışmalarında iç tutarlılık katsayıları .87 ve .92 , madde toplam puan korelasyonları ise .20 ve .50 arasında bulunmuştur. Geçerlik çalışmalarında ise Beck Depresyon Ölçeği ile korelasyonu .30 ve .65, Otomatik düşünceler Ölçeği ile .43 ve .64 olarak bulunmuştur. Şahin ve Şahin'in Türkiye'de yaptıkları güvenirlik çalışmasında iç 
tutarlılık katsayısı 79, madde toplam puan korelasyonları ortalaması ise .34 olarak saptanmıştır. Geçerlik çalışmasında Beck Depresyon Ölçeği ile korelasyonu .9 Otomatik Düşünceler Ölçeği ile .29 korelasyon bulunmuştur. Ölçekten alınan toplam puanların yüksekliği, bireyin fonksiyonel olmayan tutumlarının sıklığını gösterir.

\section{Verilerin Analizi}

Verilerin analizinde öntest - sontest puan karşılaştırmalarında, puanlar arasındaki farkın anlamlılığını test eden parametrik olmayan istatistiksel tekniklerden biri olan Wilcoxon İşaretli Sıralı Testi olup, SPSS 16.0 paket programından yararlanılmıştır.

\section{Oturumlar}

Araştırma, ön-test ve son-test uygulamaları arasında gerçekleştirilen bireylerin umutsuzluk, otomatik düşünceler, fonksiyonel olmayan tutumlar ve psikolojik belirti düzeylerini olumlu yönde değişmelerine yönelik 9 oturumluk Dışavurumcu Sanat Terapi Programı'dır. Program araştırmacılar tarafından birçok kaynaktan yararlanılarak geliştirilmiştir (Capacchione, 2012; Demir ve Ylldırım, 2017; Malchiodi, 2011; Liebmann, 2004).

\section{Oturum}

\section{Araçlar}

A3 resim kağıtları, kalem, pastel boyalar, müzik, masa, sandalye.

\section{Süreç}

1. Grup üyelerine grubun amacı anlatıldı. Katılımcıların, kendilerini gruba tanıtması ve gruba katılım amaçlarını anlatmaları istendi.

2. Grup üyeleriyle birlikte kurallar belirlendi. Devam, gizlilik, alıştırmalara katılım belirlenen kurallar içindeydi.

3. Grup üyelerinden bir çiçek çizmeleri ve çizgiler ve renklerden yola çıkarak duygularına odaklanmaları ve bu duyguları ifade etmeleri istendi. 


\section{Oturum}

\section{Araçlar}

A3 resim kağıtları, kalem, pastel boyalar, müzik, masa, sandalye.

Süreç

1. Katılımcılar ile birlikte ilk oturumun değerlendirilmesi yapıldı.

2. Yönlendirilmiş imgelem yoluyla gözleri kapalı bir şekilde katılımcılara, içlerindeki çocuk ile karşılaşmak üzere zihinlerinde güvenli bir yer canlandırmaları yönünde yönerge verildi.

3. Karşılaşmış oldukları çocuğu resmetmeleri, çizdikleri resme bakıp çocuğun nasıl hissettiğini, nelerden hoşlandığı ya da hoşlanmad1ğını, nelerin değişmesini istediğini ve en çok yapmak istediği şeyin ne olduğunu içeren bir diyalog yazmaları istendi.

4. Katılımcıların duyguları çizilen resimler ve yazılan diyalog üzerinden paylaşıldı.

5. Değerlendirme yapılarak oturum sonlandırıldı.

\section{Oturum}

\section{Araçlar}

A3 resim kağıtları, kalem, pastel boyalar, müzik, masa, sandalye.

\section{Süreç}

1. İkinci oturumun değerlendirilmesi yapıldı.

2. Yönlendirilmiş imgelem yoluyla katılımcıların içlerindeki öfkeli çocuk ile karşılaşmaları sağlandı.

3. Karşılaşmış oldukları çocuğu resmetmeleri ve çizdikleri resme bakıp öfkelerini ifade etmelerine olanak sağlayacak " Seni öfkelendiren nedir? Öfkelendiğinde neler yapmak istiyorsun? " gibi sorular ile duygularını ifade eden bir diyalog yazmaları yönünde yönerge verildi.

4. Katılımcılardan, duygularının çizilen resimler ve yazılan diyalog üzerinden paylaşmaları istendi.

5. Değerlendirme yapılarak oturum sonlandırıldı.

\section{Oturum}

\section{Araçlar}

A3 resim kağıtları, A4 kağıdı, kalem, pastel boyalar, müzik, masa, sandalye. 
Süreç

1. Bir önceki oturumun değerlendirilmesi yapıldı.

2. Üçüncü oturumda çizilen resimler üzerinden duygular paylaşıldı.

3. Öfkeli çocuk annesi ve babasına benziyor mu? sorusu tartışıldı.

4. Katılımcılar kendi içlerindeki çocuğa özür ve sevgi mektubu yazdilar.

5. Değerlendirme yapılarak oturum sonlandırıldı.

\section{Oturum}

\section{Araçlar}

A3 resim kağıtları, A4 kağıdı, kalem, pastel boyalar, müzik, masa, sandalye.

Süreç

1. Dördüncü oturumun değerlendirilmesi yapıldı.

2. Freddy Kempf'den Beethoven'ın Pathetique Movement 1 parçası eşliğinde katılımclar kendi içlerindeki eleştirel anne ve babayı pastel boyalar kullanarak resmettiler.

3. Yapılan resimler yorumlandi.

4. Kendilerini eleştirdikleri özelliklerin kendi anne ve babaları tarafından eleştirildikleri özellikler olup olmadığı sorgulandı. Alıştırmadan çıkan sonuç; üyelerin kendilerini acımasızca eleştirdikleri özelliklerinin birçoğunun kendi anne ve babaları tarafından eleştirildikleri özellikler olduğu yönünde idi.

\section{Oturum}

\section{Araçlar}

A3 resim kağıtları, A4 kağıdı, kalem, pastel boyalar, müzik, masa, sandalye

Süreç

1. Beşinci oturumun değerlendirilmesi yapıldı.

2. Oturum öncesi araştırmacı tarafından hazırlanmış olan karşılıklı boş sandalyelerin resimleri katılımcılara verildi.

3. Sandalyelerden birine katılımcılardan içlerindeki eleştirel anne ve babayı diğerine ise içlerindeki besleyici ve onaylayıcı anne ve babayı çizmeleri istendi. 
4. Karşılıklı ebeveynler arasında bir diyalog geliştirildi ve katılımcılar duygularını çizilen resimler üzerinden paylaştılar.

5. Hatalarından dolayı fazla eleştirici bir tutum sergileyerek kendilerini yargıladıkları için katılımcılardan kendilerine bir özür mektubu yazmaları istendi.

\section{Oturum}

\section{Araçlar}

Dergiler, makas, yapıştırıcı, kalem, pastel boyalar, müzik, masa, sandalye. Süreç

1. Bir önceki oturumun değerlendirilmesi yapıldı

2. Grup üyeleri dergilerden üzüntülerine, endişelerine yakın bulduğu resimleri keserek karton üzerine yapıştırdılar.

3. Kolaj tamamlandıktan sonra kolaj genelinin nasıl göründüğü ve neler hissettirdiği her bir grup üyesi tarafından yorumlanması sağlandı.

4. Katılımcılar, kesip yapıştırdıkları parçalar üzerinden duygularını paylaştılar.

\section{VIII. oturum}

\section{Araçlar}

A4 kağıdı, kalem, pastel boyalar, müzik, masa, sandalye.

\section{Süreç}

1. Bir önceki oturumun değerlendirilmesi yapıldı.

2. Bu zamana kadar yaptıkları hatalardan en önemli 3 tanesini belirleyip bunları yazmaları istendi.

3. "Bu yaptığınız hatalar hayatınıza neler kattı? Nelerin gerçekleşmesine vesile oldu? Size bir şeyler öğretti mi ? " soruları tartışıldı

4. Kendilerini eleştirdikleri özelliklerin grubun diğer üyelerinde de var olup olmadığı sorgulandı. Alıştırmadan çıkan sonuç; üyelerin kendilerini acımasızca eleştirdikleri özelliklerinin birçoğunun diğer grup üyelerinde de var olduğu yönünde idi.

5. Kendilerine hata yapmak için izin verdikleri bir izin kağıdı yazmaları ve altına da kendi imzaların atmaları istendi. 
IX. Oturum

Araçlar

10x15 cm karton, kalem, pastel boyalar, müzik, masa, sandalye.

Süreç

1. Sekizinci oturumun değerlendirilmesi yapıldı.

2. Katılımcılara kendi kartpostallarını hazırlayabilecekleri 10x15 cm büyüklügünde kartonlar verildi.

3. Hazırlamış oldukları kartpostallara pişmanlık, umut, komik deneyim, fantezi, inanç, korku, ihanet, erotik arzu, ve duygularına yönelik bir sırlarını yazmaları istendi.

4. Uygulama bittikten sonra arzu eden katılımcı sırrını paylaştılar.

5. Son oturum olan dokuzuncu oturumda genel bir özet yapıldı. Katılımcilardan ilk oturum ile son oturum arasında kendilerindeki değişimlere dair geri bildirimler alındıktan sonra katılımcılara son test uygulandi.

\section{Programın Uygulanmasi}

Ekim 2015 - Aralık 2015 tarihleri arasında toplam 9 hafta süreyle, hazırlanan program katılımcılara uygulanmıştır. Program 14 katılımcı ile başlamış ve üç katılımcı oturumlara devam etmemiştir. Bu nedenle 11 katılımcıdan alınan veriler analiz edilmiştir. Oturumlar haftada bir kez 180 dakika süreyle uygulanmıştır.

\section{Bulgular}

$\mathrm{Bu}$ bölümde araştırmada elde edilen bulgular yer almaktadır. Araştırmada dişavurumcu sanat terapisinin bireylerin umutsuzluk ve psikolojik belirti düzeylerine etkisi incelenmiştir.

Tablo 2'de görüldüğü gibi çalışma grubunun umutsuzluk, psikolojik belirtiler, otomatik düşünceler ve fonksiyonel olmayan tutumlar ölçeğinden aldıkları puanların aritmetik ortalaması ön- test puanlarının aritmetik ortalamasından düşüktür. 
Tablo 2: Çalışma Grubundaki Bireylerin Kısa Semptom Envanteri (KSE), Beck Umutsuzluk Ölçeği (BUÖ), Otomatik Düşünceler Ölçeği (ODÖ) ve Fonksiyonel Olmayan Tutumlar Ölçeği (FOTÖ) Öntest ve Sontest Puan Ortalamalarn

\begin{tabular}{|c|c|c|c|c|}
\hline & & $\mathbf{N}$ & Ortalama & Ss \\
\hline \multirow{2}{*}{ Somatizasyon } & Öntest & 11 & 6,81 & 4,214 \\
\hline & Sontest & 11 & 3,45 & 2,161 \\
\hline \multirow{2}{*}{ Obsesif Kompulsif } & Öntest & 11 & 9,45 & 4,297 \\
\hline & Sontest & 11 & 6,09 & 4,437 \\
\hline \multirow{2}{*}{ Kişiler Arası Duyarlılık } & Öntest & 11 & 7,64 & 3,775 \\
\hline & Sontest & 11 & 4,00 & 2,530 \\
\hline \multirow{2}{*}{ Depresyon } & Öntest & 11 & 9,64 & 5,697 \\
\hline & Sontest & 11 & 5,36 & 2,618 \\
\hline \multirow{2}{*}{ Kayg1 } & Öntest & 11 & 10,81 & 11,574 \\
\hline & Sontest & 11 & 5,18 & 2,822 \\
\hline \multirow{2}{*}{ Öfke-Düşmanlık } & Öntest & 11 & 6,00 & 3,130 \\
\hline & Sontest & 11 & 4,18 & 1,721 \\
\hline \multirow{2}{*}{ Fobik-Anksiyete } & Öntest & 11 & 4,91 & 2,468 \\
\hline & Sontest & 11 & 2,27 & 1,555 \\
\hline \multirow{2}{*}{ Paranoid Düşünce } & Öntest & 11 & 7,54 & 2,978 \\
\hline & Sontest & 11 & 5,00 & 3,033 \\
\hline \multirow{2}{*}{ Psikotizm } & Öntest & 11 & 5,27 & 3,289 \\
\hline & Sontest & 11 & 2,64 & 2,335 \\
\hline \multirow{2}{*}{ Ek Maddeler } & Öntest & 11 & 5,09 & 3,144 \\
\hline & Sontest & 11 & 3,27 & 2,412 \\
\hline \multirow{2}{*}{ Umutsuzluk } & Öntest & 11 & 7,73 & 5,850 \\
\hline & Sontest & 11 & 4,64 & 2,730 \\
\hline \multirow{2}{*}{ Otomatik Düşünceler (ODÖ) } & Öntest & 11 & 65,72 & 20,645 \\
\hline & Sontest & 11 & 50,45 & 15,319 \\
\hline \multirow{2}{*}{ Fonsiyonel Olmayan Tutumlar (FOTÖ) } & Öntest & 11 & 1,38 & 22,782 \\
\hline & Sontest & 11 & 1,21 & 17,339 \\
\hline
\end{tabular}

Öntest-sontest puan ortalamaları arasında anlamlı bir farkın olup olmadığ $\mathbf{1}$ Wilcoxon işaretli sıralar testi ile analiz edilmiş olup sonuçlar tablo 3 'de verilmiştir. 
Tablo 3: Kisa Semptom Envanteri (KSE), Beck Umutsuzluk Ölçeği (BUÖ), Otomatik Düşünceler Ölçeği (ODÖ) ve Fonksiyonel Olmayan Tutumlar Ölçeği (FOTÖ) Öntest - Sontest Wilcoxon İşaretli Sıralar Testi Sonuçları

\begin{tabular}{|c|c|c|c|c|c|c|}
\hline & $\begin{array}{c}\text { Sontest-Önt- } \\
\text { est }\end{array}$ & $\mathbf{N}$ & $\begin{array}{c}\text { Sira Ortala- } \\
\text { ması }\end{array}$ & $\begin{array}{c}\text { Sira Top- } \\
\text { lami }\end{array}$ & $\mathbf{z}$ & $\mathrm{p}$ \\
\hline \multirow{3}{*}{ Somatizasyon } & Negatif Sira & 7 & 4,00 & 28,00 & $-2,410$ & ,016 \\
\hline & Pozitif Sira & 0 & ,00 & ,00 & & \\
\hline & Eşit & 4 & & & & \\
\hline \multirow{3}{*}{$\begin{array}{l}\text { Obsesif Kom- } \\
\text { pulsif }\end{array}$} & Negatif Sira & 8 & 6,38 & 51,00 & $-2,409$ & ,016 \\
\hline & Pozitif Sira & 2 & 2,00 & 4,00 & & \\
\hline & Eşit & 1 & & & & \\
\hline \multirow{3}{*}{$\begin{array}{l}\text { Kişilerarası } \\
\text { Duyarlılık }\end{array}$} & Negatif Sira & 8 & 4,50 & 36,00 & $-2,640$ & ,008 \\
\hline & Pozitif Sira & 0 & ,00 & & & \\
\hline & Eşit & 3 & & & & \\
\hline \multirow{3}{*}{ Depresyon } & Negatif Sira & 8 & 6,94 & 55,50 & $-2,011$ & ,044 \\
\hline & Pozitif Sira & 3 & 3,50 & 10,50 & & \\
\hline & Eşit & 0 & & & & \\
\hline \multirow{3}{*}{ Kayg1 } & Negatif Sira & 9 & 5,39 & 48,50 & $-2,157$ & ,031 \\
\hline & Pozitif Sira & 1 & 6,50 & 6,50 & & \\
\hline & Eşit & 1 & & & & \\
\hline \multirow{3}{*}{ Öfke-düşmanlık } & Negatif Sira & 7 & 7,71 & 54,00 & $-1,891$ & ,059 \\
\hline & Pozitif Sıra & 4 & 3,00 & 12,00 & & \\
\hline & Eşit & 0 & & & & \\
\hline \multirow{3}{*}{ Fobik-anksiyete } & Negatif Sira & 8 & 5,25 & 42,00 & $-2,320$ & ,020 \\
\hline & Pozitif Sira & 1 & 3,00 & 3,00 & & \\
\hline & Eşit & 2 & & & & \\
\hline \multirow{3}{*}{$\begin{array}{l}\text { Paranoid } \\
\text { düşünce }\end{array}$} & Negatif Sira & 8 & 6,06 & 48,50 & $-2,149$ & ,032 \\
\hline & Pozitif Sira & 2 & 3,25 & 6,50 & & \\
\hline & Eşit & 1 & & & & \\
\hline \multirow{3}{*}{ Psikotizm } & Negatif Sira & 8 & 5,44 & 43,50 & $-2,501$ & ,012 \\
\hline & Pozitif Sira & 1 & 1,50 & 1,50 & & \\
\hline & Eşit & 2 & & & & \\
\hline \multirow{3}{*}{ Ek maddeler } & Negatif Sira & 5 & 3,00 & 15,00 & $-2,236$ & ,025 \\
\hline & Pozitif Sira & 0 & ,00 & ,00 & & \\
\hline & Eşit & 6 & & & & \\
\hline \multirow{3}{*}{ Umutsuzluk } & Negatif Sira & 8 & 4,94 & 39,50 & $-2,018$ & ,044 \\
\hline & Pozitif Sira & 1 & 5,50 & 5,50 & & \\
\hline & Eşit & 2 & & & & \\
\hline \multirow{3}{*}{$\begin{array}{l}\text { Otomatik } \\
\text { düşünceler }\end{array}$} & Negatif Sira & 8 & 6,94 & 56,50 & $-2,002$ & ,044 \\
\hline & Pozitif Sira & 3 & 3,50 & 10,50 & & \\
\hline & Eşit & 0 & & & & \\
\hline
\end{tabular}




\begin{tabular}{cclcccc}
\hline \hline & Negatif Sira & 9 & 6,72 & 60,50 & $-2,447$ &, 014 \\
FOTÖ & Pozitif Sıra & 2 & 2,75 & 5,50 & & \\
& Eşit & 0 & & & & \\
\hline
\end{tabular}

${ }^{*}$ Negatif siralar temeline dayalı

Tablo 3 incelendiğinde çalışma grubunun umutsuzluk ölçeği, otomatik düşünceler ölçeği (ODÖ), fonksiyonel olmayan tutumlar ölçeği (FOTÖ), Kısa Semptom Envanteri (KSE) alt ölçeklerinden somatizasyon, obsesif kompulsif bozukluk, kişiler arası duyarlılık, depresyon, anksiyete, fobik anksiyete, paranoid düşünce ve psikotizm öntest-sontest puanları arasinda anlamlı derecede farklılaştığı görülmüştür (umutsuzluk; $z=-2,018$ $\mathrm{p}<.05$, otomatik düşünceler; $\mathrm{z}=-2,002 \mathrm{p}<.05$, fonksiyonel olmayan tutumlar; $\mathrm{z}=-2,447 \mathrm{p}<.05$, somatizasyon; $\mathrm{z}=-2,410 \mathrm{p}<.05$, obsesif kompulsif bozukluk; $z=-2,409 p<.05$, kişiler arası duyarlılık; $z=-2,640 p<.05$, depresyon; $\mathrm{z}=-2,011 \mathrm{p}<.05$, anksiyete; $\mathrm{z}=-2,157 \mathrm{p}<.05$, fobik anksiyete; $\mathrm{z}=-2,320 \mathrm{p}<.05$, paranoid düşünce; $z=-2,149 \mathrm{p}<.05$, psikotizm; $\mathrm{z}=-2,501 \mathrm{p}<.05$, ek maddeler; $z=-2,236 p<.05)$. Öfke puanları arasında ise anlamlı derecede farkl1laşma görülmemiştir (öfke; $z=-1,891$ p>.05).

\section{Tartışma ve Yorum}

Bu çalışmada dişavurumcu sanat terapi yöntem ve teknikleri ile hazırlanan grup terapi programina katılan bireylerin, program öncesi umutsuzluk, otomatik düşünceler, fonksiyonel olmayan tutumlar ve psikolojik belirti puan ortalamaları ile program sonrası puan ortalamaları arasında anlamlı düzeyde farklılaşma olup olmadığı sınanmıştır. İstatistiksel analiz sonucu terapi programının, bireylerin umutsuzluk, otomatik düşünceler, fonksiyonel olmayan tutumlar ve Kısa Semptom Envanteri (KSE) alt ölçeklerinden somatizasyon, obsesif kompulsif bozukluk, kişiler arası duyarlılık, depresyon, anksiyete, fobik anksiyete, paranoid düşünce ve psikotizm belirti düzeylerini azaltmada olumlu bir etkiye sahip olduğunu ancak öfke düzeylerini azaltmada etkili olmadığını göstermektedir.

Araştırma bulgularından biri dışavurumcu sanat terapisi programının umutsuzluğu azaltmada etkili olduğudur. Sanat terapisi, benlik değerindeki hasarı onarabileceği gibi, terapistin geri bildirimleri ile kişinin içgörü, 
farkındalık ve iletişim becerilerinde de artışa neden olabilir. Sanat etkinlikleri, vakit geçirme veya bir hobi aracı değil, ruhsal tedavinin bir parçası konumundadır (Killick, 1993; Killick ve Schaveiren, 2003). Sanat terapisi bireylerin kendilerini fiziksel, psikolojik ve ruhsal olarak ifade edebilecekleri yeni yollar bulmasını sağlar. Bu durum umutsuzluk ve çaresizliklerine yönelik kontrol hislerini arttırır ve mücadele becerilerini geliştirir (Malchiodi, 2003).

Analizler sonucunda elde edilen bulgular, sanat terapisi programina katılan bireylerin sahip olduğu otomatik düşünceler ve fonksiyonel olmayan tutumların düzeylerinde de, deneysel işlemin sona ermesinden sonra gerçekleştirilen son-test ölçümlerinde, ön-test ölçümlerine oranla anlamlı düzeyde bir azalmanın olduğu görülmüştür. Bu araştırmayı önemli kılan nedenlerden birisi, bu çalışma kapsamında olan yazına bakıldığında, yurt dışında ve ülkemizde dışavurumcu sanat terapisinin otomatik düşünceler ve fonksiyonel olmayan tutumlara yönelik etkisini araştıran çalışmalara hiç rastlanmamasıdır.

Çalışmada; resim, müzik, kolaj gibi sanat terapisi yöntemleri kullanılarak grup paylaşımı ve grup tartışmalarına yer verilmiştir. Bu etkinliklerin katılımcıların düşüncelerine ilişkin farkındalık kazanmalarında, duygularını dışa vurarak rahatlamalarında böylece psikolojik belirti düzeylerinin azalacağı beklenmekteydi. Bu beklentiler Kısa Semptom Envanteri (KSE) alt ölçeklerinden; somatizasyon, obsesif kompulsif bozukluk, kişiler arası duyarlılık, depresyon, anksiyete, fobik anksiyete, paranoid düşünce ve psikotizm için doğrulanmıştır. Alan yazında sanat terapisi yönteminin kullanıldığı grup çalışmalarına bakıldığında obsesif kompulsif bozukluğu, fobik anksiyeteyi, paranoid düşünce ve psikotizmi azaltmaya yönelik bir çalışmaya rastlanmamıştır.

Theorell ve arkadaşlarının (1998) yaptıkları çalışmada psikolojik kökenli olan bedensel rahatsızlıklarda da yeteneklerin sanatla ifade edilmesi yönünde cesaretlendirilmesi, sanatın bireylerin bedensel ve ruhsal durumları arasında bir köprü olduğu görülmüştür. Çalışmanın sonucuna göre katılımcların psikosomatik belirti düzeylerinde belirgin bir azalma ile birlikte depresyon ve kaygı belirtilerinde de azalma görülmüştür.

Demir ve Yıldırım (2017) tarafından 17-18 yaş arasında değişen üniversite sınavına hazırlanan lise son sınıf öğrencilerine sanatla terapi programı 
uygulanmiştır. Program sonucunda öğrencilerin depresyon ve anksiyete düzeylerinde belirgin bir azalma olduğu saptanmıştır.

Kişilerarası ilişkilerde duyarlılığa sahip bireyler için diğerlerinin sözel ya da sözel olmayan iletişim biçimleri, duyguları, düşünceleri ve davranışları önemlidir. Çünkü kişilerarası ilişkilerinde duyarlı olan bireyler, ilişkilerinde diğer bireyler için önemli olmayan problemlere kolaylıkla incinen; basit, sıradan ve çözülmesi oldukça kolay sorunları büyüterek ilişkinin ilerlemesinde engelleyici bir rol üstlenen, hassas bireylerdir (Boyce ve Mason, 1996). Gussak (2007) sanat terapisi yöntem ve tekniklerini kullanarak hapishanede gerçekleştirdiği bir çalışmada, mahkûmların agresif davranışlarını kendi güvenliklerini sağlamaları ile ilişkilendirilmiş ve sanat terapisinin bu tür agresif davranışları ortadan kaldırmakla kalmayıp aynı zamanda bu bireylerin düşünce ve duygularını, diğer bireyler ile olan iletişimlerini de olumlu etkilediğini bildirmiştir. Çalışmaya katılan mahkûmların depresif belirtilerinde de belirgin bir azalma saptanmıştır.

Literatürde kanser ile mücadele etmeyi sürdüren bireylerde sanat terapinin etkinliğini değerlendiren çalışmalarda bireylerin kanser ve yaşamlarıyla ilgili farkındalıklarının arttığı, duygusal dışavurumlarının daha etkin gerçekleştiği ve psikolojik iyilik halinin olumlu yönde geliştiği belirtilmektedir (Oster ve ark., 2007; Ponto ve ark., 2003; Nainis, 2008; Deane, Fitch, Carman, 2000). Yapılan diğer çalışmalarda sanat terapisi uygulamalarının yorgunluk, stres, anksiyete, depresif belirtilerinde belirgin bir azalma ve sağlıkla ilintili yaşam kalitesinde ise belirgin artışa neden olduğu, bireylerin benlik saygılarının arttığı, kişilerarası ilişkilerinin geliştiği saptanmıştır. (Bar-Sela ve ark., 2007; Collie, Bottorff ve Long, 2006; Dilawari ve Tripathi, 2014).

Turetsky ve Hays (2003) geçmişlerini geride bırakmaları nedeniyle bir kayıp duygusu yaşayan ve bu nedenle bir nevi yas sürecine giren yaşlı bireylerle yaptıkları bir çalışmada, sanat terapisinin depresif semptomları azaltarak daha sağlıklı bir psikolojik sürece neden olduğunu göstermişlerdir. Kaya (2014), üniversite öğrencilerinde sanat terapisinin etkinliğini sınadığı çalışmada psikolojik iyi oluş ölçeği ön-test son test puanları arasinda anlamlı fark bulmuştur. Bu sonuç literatürde sanat terapisinin psikolojik iyi oluş üzerinde olumlu etkisi olduğunu bildiren diğer araştırmalarla örtüşmektedir (Duran-Oguz, 2006; Puig ve ark., 2006). 
Araştırma bulgularından biri de, dışavurumcu sanat terapisi teknikleri kullanılarak yapılan grup programına katılan bireylerin Kısa Semptom Envanteri (KSE) alt ölçeklerinden; öfke ön-test ve son-test puanları arasında anlamlı bir fark olmadığıdır. Duyguları sözel ya da sözel olmayan yollarla ifade etmenin, fiziksel ve ruhsal sağlık üzerinde olumlu etkileri olduğu bilinmektedir. Bireylerin duygularını anlamada kullanılabilecek çeşitli teknikler bulunmaktadır. Örneğin sanat ile duygusal olarak bloke olmuş, bir kişiye veya ortama karşı duygularını ifade edemeyen bireylerde semboller, çok fazla suçluluk duygusu yaratmadan bu ortam ya da kişi ile ilgili duygularının ortaya çımasına neden olabilir (Aydın, 2010; Killick, 1993). Böylece sanat terapisi katılımcıların işlevsel olmayan duygu ve düşünceleriyle bağlantılar kurarak farkındalık ve içgörü kazanmalarına yardımcı olacağından katılımcıların öfke düzeylerinde de etkili olacağı beklenmiştir. Ancak sonuçlar bu beklentiyi doğrulamamıştır.

$\mathrm{Bu}$ araştırmanın bazı sınırlılıkları vardır. Araştırmada katılımcılar, uygulanan deneysel işlemden bağımsız olarak grup çalışmasına katıldıkları için araştırmacıların kendilerinde olumlu yönde davranış değişikliği beklemelerinden dolayı bu beklentiyi boşa çıkarmamak için özel bir çaba içine girmelerinden kaynaklanan etkiyi kontrol etmek amaciyla kontrol grubu oluşturulmaması sınırlılık olarak düşünülmektedir. Araştırmanın sınırlılıklarından bir tanesi ve belki de en önemlisi bilişsel - davranışçı, psikodrama gibi sanat terapisi yöntem ve tekniklerini içermeyen alternatif bir müdahale ile karşılaştırılmamış olmasıdır. Çalışmanın önemli sınırlılıklarından biri de araştırmaya katılan bireylerin umutsuzluk düzeylerini Beck Umutsuzluk Ölçeği, bilişsel çarpıtmalarını Otomatik Düşünceler Ölçeği (ODÖ) işlevsel olmayan tutumlarını Fonksiyonel Olmayan Tutumlar (FOTÖ), psikolojik belirtilerin ise sadece Kisa Semptom Envanteri (KSE), ile değerlendirilmiş olması, bir psikiyatrist ve psikolog tarafından bireylerin klinik muayenesinin yapılmamış olmasıdır.

Sonuç olarak son yıllarda Türkiye'de sanat terapisine yönelik ilginin arttığı görülmektedir; ancak konu ile ilgili Türkçe alan yazın bu ilgiyi karşılamakta yetersiz kalmaktadır. Bu konuda ülkemizde yapılmış çalışmaların yeterli olmaması elde ettiğimiz sonuçları karşılaştırmamızı sınırlamaktadır. Sanat terapisinin etkinliğini değerlendiren yapısal çalışmaların yapılmasının yararlı olacağı kanaatindeyiz. Sanat terapisi üzerine eğitim 
almış uzman sayısının artması ile birlikte tüm dünyada uzun yıllardır kullanılmakta olan bu modelin ülkemizde de daha iyi tanınacağı, uygulanacağ1 ve araştırmalara konu olacağı düşünülmektedir.

\section{KAYNAKÇA}

Akhan, L.U.(2012). Psikopatolojik sanat ve psikiyatrik tedavide sanatın kullanılışı. Yükseköğretim ve Bilim Dergisi, 2(2), 132- 135.

Aydın, B. (2010). Tıbbi Sanat Terapisi. Psikiyatride Güncel Yaklaşımlar, 4(1), 69-83.

Aydın, G., ve Aydın, O. (1990). Otomatik düşünceler ölçeğinin geçerlik ve güvenirliği. Psikoloji dergisi, 24, 51-55.

Bar-Sela, G., Atid, L., Danos, S., Gabay, N., \& Epelbaum, R. (2007). Art therapy improved depression and influenced fatigue levels in cancer patients on chemotherapy. Psychooncology, 16, 980-984.

Beck A. T, Rush A. J, Shaw B. F, Emery G. (1979), Cognitive Therapy of Depression. New York: The Guilford Press.

Beck JS (2001) Bilişsel Terapi: Temel İlkeler ve Ötesi. (Çev. N Hisli Şahin), (Çev. Ed. F Balkaya, A İlden Koçkar), Türk Psikologlar Derneği Yayinları, Ankara, 2006.

Beck, A. T. (1976) Cognitive therapy and the emotional disorders. (Çev. A. Türkcan, V. Öztürk), Bilişsel Terapi ve Duygusal Bozukluklar. Litera Yayıncılık, İstanbul, 2008.

Beck, A. T., Freeman, A., \& Davis, D. D. (2004). Cognitive therapy of personality disorders (2nd ed.). New York: The Guilford Press.

Beck, A., T., Lester, D., Trexler, L.,(1974) “ The Measurement of Pessimism, Beck Hopelessness Scale", Journal of Consulting and Clinical Psycho$\log y, 42(6)$

Boyce, P. \& Mason, C. (1996). An overview of depression-prone personality traits and the role of interpersonal sensitivity. Australian and New Zealand Journal of Psychiatry, 30(1), 90-103.

Capacchione, L. (2012). Sanat terapisiyle iyileşmek. Kaknüs yayınları: İstanbul.

Case, C., \& Dalley, T. (2006). Handbook of art therapy. (2 rd ed. pp.1-10). London: Routledge. 
Collie, K., Bottorff, J.L., \& Long, B.C.(2006). A narrative view of art therapy and art making by women with breast cancer. J Health Psychology, 11(5),761-775

Corey, G. (2008), Psikolojik Danışma, Psikoterapi Kuram Ve Uygulamaları. (Yedinci baskı). (Çev. T.Ergene), Mentis Yayıncılık, Ankara (Orijinal çalışma basım tarihi 2005).

Coşkun, S., Yıldız, Ö., \& Yazıcı, A. (2010). Psikiyatrik Rehabilitasyonda Fotoğrafın Kullanımı: Bir Ön Proje. Psikiyatri Hemşireliği Dergisi, 1(3):121-127

Cunningham S, Gunn T, Alladin A, Cawthorpe D. Anxiety, depression and hopelessness in adolescents: A structural equation model. J Can Acad Child Adolesc Psychiatry 2008;17:137-44.

Çakar, F. S. (2014). Otomatik Düşüncelerin Umutsuzluk Üzerindeki Etkisinin İncelenmesi: Benlik Saygısının Aracılık Rolü. Kuram ve Uygulamada Ĕ̆itim Bilimleri, 14(5), 1-16.

Deane, K., Fitch, M., \& Carman, M.(2000). An innovative art therapy program for cancer patients. Canadian oncology nursing journal,10(4),147--151.

Demir, V., \& Yıldırım, B. (2017). Sanatla Terapi Programının Üniversite Sınavına Hazırlanan Öğrencilerin Depresyon, Anksiyete ve Stres Belirti Düzeylerine Etkililiği. Ege Eğitim Dergisi, (18) 1: 311-344.

Derogatis, L. R. (1992). BSI: Administration, scoring, and procedures manual-II. Towson, MD: Clinical Psychometric Research.

Dilawari, K., \& Tripathi, N. (2014). Art therapy: A creative and expressive process, Indian Journal of Pozitive Psychology, 5(1), 81-85

Dilbaz, N., \& Seber, G. (1993). Umutsuzluk kavrami: Depresyon ve intiharda önemi. Kriz Dergisi, 1(3), 134-138.

Durak, A. (1994). Beck Umutsuzluk Ölçeğinin Geçerlik ve Güvenirlik Çalışması. Türk Psikoloji Dergisi, 9 (31), 1-11.

Duran-Oğuz, N. (2006). Wellness among Turkish University Students: Investigating the Construct and Testing the Effectiveness of an Artbased Wellness Program. Unpublished doctoral dissertation, Middle East Technical University, Ankara. 
Duy, B. (2003). Bilişsel-Davranışçı Yaklaşıma Dayalı Grupla Psikolojik Danışmanın Yalnızlık ve Fonksiyonel Olmayan Tutumlar Üzerine Etkisi, Yayımlanmamış Doktora Tezi, Ankara Üniversitesi Eğitim Bilimleri Enstitüsü, Ankara.

Edwards, D. (2014). Art therapy. Sage.

Eisen, R.A., Kearney, A.C. (1995), "Practitioner's Guide to Treating Fear and Anxiety in Childernand", Adolescents. New Jersey: Jason Aronson Inc.

Gençöz, F., Vatan, S., \& Lester, D. (2006). Umutsuzluk, Çaresizlik ve Talihsizlik Ölçeği ‘nin Türk örnekleminde güvenirlik ve geçerlik ça1ışması. Kriz Dergisi, 14(1), 21-29.

Geue, K.L., Goetze, H., Buttstaedt, M., Kleinert E., Richter, D., \&Singer S. (2010). An overview of art therapy interventions for cancer patients and the results of research, Complementary Therapies in Medicine, 18(3-4), 160-170

Gussak, D. (2007). The effectiveness of art therapy in reducing depression in prison populations. International Journal of Offender Therapy and Comparative Criminology, 51(4), 444-460.

Hollon, S.; Kendal, P. (1980). “Cognitive self-statement in depression: Clinical validation of an automatic thoughts questionnaire". Cognitive Therapy and Research. 4.

Kar, Ö., \& Toros, F. (2015). Aile İçi Şiddet ve Çocuk İstismarı Olgularında Sanat Terapisi. Hacettepe University Faculty of Health Sciences Journal, 1.

Karasar, N. (2014). Bilimsel araştırma yöntemi. (26.baskı). Ankara Nobel Yayınevi.

Kaya, A. (2014). Dışavurumcu Sanat Terapinin Üniversite Öğrencilerinde Akış Durumu Ve Psikolojik İyi Oluş Üzerindeki Etkisi.

Killick, K. (1993). Working With Psychotic Processes in Art Therapy. Psychonalytic Psychotherapy, 7(1), 25-38.

Killick, K., Schaveiren, J. (2003). Sanat Psikoterapi ve Psikoz. Yelkovan Yayinclik.

Liebmann, M. (2004). Art therapy for groups: A handbook of themes and exercises. Psychology Press. 
Malchiodi CA. Using art therapy with medical support groups. In Handbook of Art Therapy, 1st ed. (Ed CA Malchiodi):351-361. New York, Guilford Press, 2003.

Malchiodi, C. A. (Ed.). (2011). Handbook of art therapy. Guilford Press.

Malchiodi, C.A.(2005). Expressive Therapies History, Theory, and Practice. In. C.A. Malchiodi (Ed.), Expressive Therapies (pp.1-15). Newyork: Guilford press.

Nainis, N. A. (2008). Approaches to art therapy for cancer inpatients: Research and practice considerations. Art Therapy, 25(3), 115-121.

Nainis, N., Paice, J. A., Ratner, J., Wirth, J. H., Lai, J., \& Shott, S. (2006). Relieving symptoms in cancer: innovative use of art therapy. Journal of pain and symptom management, 31(2), 162-169

Norman, W. H., Miller, I. W., \& Dow, M. G. (1988). Characteristics of depressed patients with elevated levels of dysfunctional cognitions. Cognitive Therapy and Research, 12(1), 39-51.

O'Connor, L. E., Berry, J. W., Weiss, J., \& Gilbert, P. (2002). Guilt, fear, submission, and empathy in depression. Journal of Affective Disorders, 71, 19-27.

Oster, I., Magnusson, E., Thyme, K.E., Lindh, J., \& Aström, S. (2007). Art therapy for women with breast cancer: the therapeutic consequences of boundary strengthening. The Arts in Psychotherapy, 34, 277288.

Ponto, J.A., Frost, M.H., Thompson, R., Allers, T., Will T.R., Zahasky K., et al.(2003). Stories of breast cancer through art. Oncoloy Nursing Forum, 30(6), 1007- 1013.

Puig, A., Lee, S. M., Goodwin, L., \& Sherrard, P. A. (2006). The efficacy of creative arts therapies to enhance emotional expression, spirituality, and psychological well-being of newly diagnosed Stage I and Stage II breast cancer patients: A preliminary study. The Arts in Psychotherapy, 33(3), 218-228.

Savaşır, I., \& Şahin, N. H. (1997). Bilişsel-davranışçı terapilerde değerlendirme: Sık kullanılan ölçekler. Ankara: Türk Psikologlar Derneğgi Yayinlari, 9 .

Seber, G. (1991). Beck Umutsuzluk Ölçeğinin geçerlik ve güvenirliği üzerine bir çalışma. Doktora Tezi, Eskişehir: Anadolu Üniversitesi Sosyal Bilimler Enstitüsü. 
Şahin, N. H., \& Durak, A. (1994). Kısa Semptom Envanteri: Türk gençleri için uyarlanması. Türk Psikoloji Dergisi, 9 (31), 44-56.

Şahin, N. H., Batıgün, A. D., \& Uğurtaş, S. (2002). Kısa Semptom Envanteri (KSE): Ergenler için kullanımının geçerlik, güvenilirlik ve faktör yapisi. Türk Psikiyatri Dergisi, 13(2), 125-135.

Şahin, N.H.; Şahin, N. (1992). "Reliability and validity of the Turkish version of the automatic thoughts questionaire". Journal of Clinical Psychology, 48, 334-340.

Theorell, T. O. R., Konarski, K., Westerlund, H., Burell, A. M., Engström, R., Lagercrantz, A. M., ... \& Thulin, K. (1998). Treatment of patients with chronic somatic symptoms by means of art psychotherapy: A process description. Psychotherapy and Psychosomatics, 67(1), 50-56.

Turetsky, C. J., \& Hays, R. E. (2003). Development of an art psychotherapy model for the prevention and treatment of unresolved grief during midlife. Art Therapy, 20(3), 148-156.

Tümkaya, S., Çelik, M., \& Aybek, B. (2011). Lise Öğrencilerinde Boyun Eğici Davranışlar Otomatik Düşünceler Umutsuzluk Ve Yaşam Doyumunun incelenmesi. Çukurova Üniversitesi Sosyal Bilimler Enstitüsü Dergisi, 20(2).

Weissman, A. N., \& Beck, A. T. (1978). Development and validation of the Dysfunctional Attitude Scale: A preliminary investigation.

Wilson, L. (1995). Symbolism and Art Therapy. Symbolism's role in the development of ego functions. American Journal of Art Therapy, 23(3),79-88.

\section{Kaynakça Bilgisi / Citation Information}

Demir, V. (2017). Dişavurumcu sanat terapisinin psikolojik belirtiler ile bilişsel işlevlere etkisi. OPUS - Uluslararası Toplum Araştırmaları Dergisi, 7(13), 575-598. 